\title{
Effects of amino acid composition in pig diet on odorous compounds and microbial characteristics of swine excreta
}

Neeraja Recharla ${ }^{1 \dagger}$, Kihyun Kim $^{2 \dagger}$, Juncheol Park ${ }^{2}$, Jinyoung Jeong ${ }^{2}$, Yongdae Jeong ${ }^{2}$, Hyunjeong Lee ${ }^{2}$, Okhwa Hwang ${ }^{2}$, Jaehyoung Ryu', Youlchang Baek², Youngkyun $\mathrm{Oh}^{2}$ and Sungkwon Park ${ }^{1 *}$ (D)

\begin{abstract}
Background: Major amino acids in pig diets are Lys, Met, Thr, and Trp, but little is known about the requirements for the other essential amino acids, especially on odorous compounds and microbial characteristics in feces of growing-finishing pigs. To this end, different levels of amino acid composition added to diets to investigate the effects of amino acid composition on microbial characteristics and odorous compounds concentration.

Methods: A total eight $(n=8)$ barrows (Landrace $\times$ Yorkshire $\times$ Duroc) with an average bodyweight of $89.38 \pm 3$. $3 \mathrm{~kg}$ were individually fed diets formulated by Korean Feeding Standards 2007 (old version) or 2012 (updated with ideal protein concept) in metabolism crates with two replication. After 15-day adaptation period, fresh faecal samples were collected directly from pigs every week for 4 weeks and analysed for total volatile fatty acids (VFA), phenols and indoles by using gas chromatography. The nitrogen was determined by Kjeldahl method. Bacterial communities were detected by using a $454 \mathrm{FLX}$ titanium pyrosequencing system.
\end{abstract}

Results: Level of VFA tended to be greater in 2012 than 2007 group. Among VFAs, 2012 group had greater $(p<0.05)$ level of short chain fatty acids (SCFA) than control.Concentration of odorous compounds in feces was also affected by amino acid composition in pig diet. Levels of ammonium and indoles tended to be higher in 2012 group when compared with 2007 group.Concentration of phenols, p-cresol, biochemical oxygen demand, and total Kjeldahl nitrogen, however, were lower $(P<0.05)$ in 2012 treatment group compare to 2007. The proportion of Firmicute phylum were decreased, while the Bacteriodetes phylum proportion increased and bacterial genera including Coprococcus, Bacillus, and Bacteroides increased $(p<0.05)$ in 2012 compare to 2007 group.

Conclusion: Results from our current study indicates that well balanced amino acid composition reduces odor by modulating the gut microbial community. Administration of pig diet formulated with the ideal protein concept may help improve gut fermentation as well as reduce the odor causing compounds in pig manure.

Keywords: Ideal protein, Amino acid, Growth performance, Microbial communities, Short chain fatty acid (SCFA), Pyrosequencing, Volatile odorous compounds (VOS)

\footnotetext{
* Correspondence: sungkwonpark@sejong.ac.kr

${ }^{\dagger}$ Equal contributors

'Department of Food Science \& Biotechnology, Sejong University, 209

Neundong-ro, Gwangjin-gu, Seoul 05006, South Korea

Full list of author information is available at the end of the article
} 


\section{Background}

Consumption of meat and meat products have been increased dramatically probably due to their higher incomes in Korea [1]. Each Korean ate $9.5 \mathrm{~kg}$ of beef \& veal, $28.4 \mathrm{~kg}$ of pork meat, $14.4 \mathrm{~kg}$ of poultry meat and $0.2 \mathrm{~kg}$ of sheep meat [2]. Especially, Korean meat consumers prefer for pork belly and Boston butt which contain high fat [3].

Production cost can be reduced by improving the market weight. To this end, The specific standards for nutritional requirements for swine were established early in 1940s by National Research Council (NRC) and in Korea, the National institute of Animal Science revised a feeding standard of swine in 2012, which adapted the ideal protein concept for pig production [4].

The source of odour from pig farming facilities is due to generation of large amounts of urine, feces and fermentation of this mixture during storage [5-7]. The odour of pig excreta is the result from anaerobic microbial degradation of the components of the feed in gut, especially some odours from proteins are more toxic and offensive sensation than the carbohydrates $[8,9]$. Many types of odorants have been identified from samples of fresh and rotten swine manure [10] and these were classified into four main groups, namely straightand branched-chain volatile fatty acids, indoles and phenols, ammonia and volatile amines, and the volatile sulfur compounds [6, 11]. Acetic acid, propionic acid and butyric acids are most common volatile fatty acids (VFA) produced from microbial conversion of dietary residues. The straight chain- VFA derived from both plant fibre and protein microbial degradation and the branched chain-VFA produced by anaerobic fermentation of amino acids such as leucine, isoleucine, lysine [7, 12]. Sulfur-containing volatile compounds such as hydrogen sulphide, dimethyl sulphide, carbonyl sulphide are originates from microbial degradation of amino acid substrates like cysteine and cysteine [13]. Aromatic compounds such as phenols, $p$-cresol, indoles and skatole are by-products of tyrosine and tryptophan degradation. These compounds are formed in the gut microflora and also during anaerobic storage of swine manure [7]. Nitrogenous compounds, ammonia and volatile amines are produced from protein degradation. Ratio of amino acids is an important element that affects the generation of odorous compounds in swine excreta $[9,14]$. Several studies have been reported that decreasing crude protein $(\mathrm{CP})$ level can be reduced faecal odorous compounds [15-17].

The term ideal protein can be defined as the protein which containing the minimum quantity of essential amino acids with maximum utilization to meet the exact nutritional amino acid requirements [18]. It refers to determine the required amounts of amino acids relative to lysine for maintenance, protein accretion, and growth performance of pigs [19, 20]. Munks et al. [21] first initiated the ideal protein concept to poultry for production of chicken egg. Later, Mitchell [22] was determined the requirement of amino acids for different animal species. In 1981, British agriculture research council (ARC) was first formulated feed based on ideal protein concept [19]. Since then, various new effective formulations have been developed based on ideal protein concept, such as Institute National de la recherche agronomique (INRA) in 1984 [23], NRC in 1988 [24], and Wang \& Fuller in 1989 [18].

Until now, there is no reports on the effects of feed formulated based on the ideal protein concept on odorous compound generation from pig farm. Therefore, the objective of this study was to compare the excretion compounds and bacterial community from faeces of pigs fed diets formulated either by 2007or 2012 Korean feeding standards of swine.

\section{Methods \\ Animals}

A total eight $(n=8)$ barrows $(\{($ Landrace $\times$ Yorkshire $) \times$ Duroc\}] with an average bodyweight of $89.38 \pm 3.3 \mathrm{~kg}$ were used for this study. These pigs were randomly allocated into two diet (2007 \& 2012) groups. Pigs were housed individually in metabolism cages and the temperature was maintained at $25^{\circ} \mathrm{C}$. The experiment was performed two replications. All procedures involving animals were approved by the National Institute of Animal Science Animal Care and Use Committee.

\section{Diets}

Feeds were formulated based on 2007 \& 2012 Korean feeding standard for swine. The form of the feed was ground form, ingredient composition for diets were given in Table 1 and nutrient content are shown in Table 2. The Feed were fed in a limited manner, approximately $1.5 \mathrm{~kg}$ was fed to each pig per twice a day at $10.00 \mathrm{am}$ and $16.00 \mathrm{pm}$. Pigs had free access to water throughout the experiment.

\section{Sampling collection}

After 15-day adaptation period, fresh faecal samples were collected directly from pigs every week for 4 weeks. The $40 \mathrm{ml}$ of each sample was taken into $50 \mathrm{ml}$ tube and then stored in a refrigerator for further analysis.

Blood sample was collected from the vein with using syringe. After collecting the blood, $2 \mathrm{ml}$ of collected blood was transferred into a tube containing anticoagulant (K2 EDTA 5.4 MG tube BD Vacutainer REF 367856) for haematology analysis, and a tube containing anticoagulant (Lithium Heparin tube BD Vacutainer REF 367884) $2 \mathrm{ml}$ of blood was added and $8 \mathrm{ml}$ of blood serum was stored in a serum separation tube (BD SST II AVANSAT REF 367953). 
Table 1 Ingredient composition of experimental diets

\begin{tabular}{lll}
\hline Ingredient (\%) & 2007 (Control) & 2012 (Treatment) \\
\hline Cornstarch & 40 & 40 \\
Corn & 40 & 40 \\
Beet pulp & 11.069 & 10.224 \\
Soybean meal & 1.077 & $\cdot$ \\
Wheat bran & 0.318 & 0.275 \\
Soybean oil & 4.425 & 5.166 \\
Salt & 0.17 & 0.174 \\
aDCP & 1.404 & 1.447 \\
Lysine & 0.563 & 0.761 \\
Methionine & 0.064 & 0.132 \\
Arginine &. & 0.139 \\
Histidine & 0.038 & 0.084 \\
Isoleucine & 0.169 & 0.314 \\
Leucine & 0.091 & 0.315 \\
Phenylalanine & 0.142 & 0.19 \\
Threonine & 0.223 & 0.347 \\
Tryptophan & 0.069 & 0.106 \\
Valine & 0.179 & 0.325 \\
Total & 100 & 100 \\
\hline
\end{tabular}

${ }^{\mathrm{a} D C P}$ digestible crude protein

\section{Growth performance study}

Initial and final body weight of pigs in each group were measured to calculate the average daily gain (ADG). Feed intake and excretion (faeces \& urine) were recorded to determine the feed efficiency by calculating feed conversion ratio (FCR).

Table 2 Nutrient content in experimental diets

\begin{tabular}{|c|c|c|}
\hline & 2012 & 2007 \\
\hline${ }^{\mathrm{a}} \mathrm{DE}, \mathrm{kcal} / \mathrm{kg}$ & 3400 & 3400 \\
\hline${ }^{\mathrm{b}} \mathrm{ME}, \mathrm{kcal} / \mathrm{kg}$ & 3360 & 3359 \\
\hline${ }^{c} \mathrm{CP}, \%$ & 8.43 & 7.822 \\
\hline $\mathrm{Ca}, \%$ & 0.45 & 0.45 \\
\hline$P, \%$ & 0.4 & 0.4 \\
\hline $\mathrm{Na}, \%$ & 0.1 & 0.1 \\
\hline lysine, \% & 0.76 & 0.64 \\
\hline methionine, \% & 0.23 & 0.17 \\
\hline arginine, $\%$ & 0.32 & 0.22 \\
\hline histidine, \% & 0.24 & 0.21 \\
\hline isoleucine, \% & 0.46 & 0.34 \\
\hline leucine, \% & 0.76 & 0.58 \\
\hline phenylalanine, \% & 0.38 & 0.36 \\
\hline threonine, \% & 0.5 & 0.4 \\
\hline tryptophan, \% & 0.14 & 0.11 \\
\hline valine, \% & 0.53 & 0.41 \\
\hline
\end{tabular}

${ }^{\mathrm{a} D E}$ Digestible energy, ${ }^{\mathrm{b}} \mathrm{ME}$ Metabolizable energy, ${ }^{\mathrm{C}} \mathrm{CP}$ Crude protein
VFA (volatile fatty acids) analysis

VFA analysis were performed by gas chromatography (GC) $(6890 \mathrm{~N}$, Agilent, Santa Clara, CA, USA), equipped with an HP - INNOWax column and a flame ionization detector.

To analyze the VFA, $5 \mathrm{ml}$ of slurry sample, $25 \%$ phosphoric acid solution and $1 \mathrm{ml}$ of saturated mercury solution (Sigma-Aldrich, St. Louis, Mo., USA) were taken into a $15 \mathrm{ml}$ tube and then the solution was centrifuged at $3134 \mathrm{x} \mathrm{g}$ for $20 \mathrm{~min}$. Thereafter, $1 \mathrm{ml}$ of the supernatant was centrifuged at $13,800 \times \mathrm{g}$ for $10 \mathrm{~min}$ and filtered through a $0.2 \mu \mathrm{m}$ filter (Whatman, Uppsala, Sweden). The filtrates were placed in $2.0 \mathrm{ml} \mathrm{GC}$ vials (Agilent, Santa Clara, Calif., USA) to measure the concentration of volatile fatty acids by GC.

$0.2 \mu$ Lwas the sample injection volume with a split ratio of 10:1. The temperature of the oven started from $80{ }^{\circ} \mathrm{C}$, and then initially increased by $20{ }^{\circ} \mathrm{C}$ per minute and kept at $120{ }^{\circ} \mathrm{C}$ for $2 \mathrm{~min}$, then the temperature was upgraded to $205{ }^{\circ} \mathrm{C}$ by increasing $10{ }^{\circ} \mathrm{C}$ per minute, finally, it was maintained at $205^{\circ} \mathrm{C}$ for $2 \mathrm{~min}$. The injection and detection ports were maintained at $250{ }^{\circ} \mathrm{C}$.

\section{VOC (volatile odorous compounds) analysis}

The concentrations of phenols and indoles in slurry sample were quantitatively measured by Gas Chromatography. For this measurement, the slurry sample was centrifuged for $20 \mathrm{~min}$ at $3134 \mathrm{x} \mathrm{g}$ at $20^{\circ} \mathrm{C} .4 \mathrm{ml}$ of the supernatant liquid was added to the $20 \mathrm{ml}$ glass bottle which containing $4 \mathrm{ml}$ of chloroform and $60 \mu \mathrm{m} 4 \mathrm{M}$ of sodium hydroxide solution. Then the mixture was centrifuged at $20{ }^{\circ} \mathrm{C}$ at $3134 \mathrm{x} \mathrm{g}$ for $20 \mathrm{~min}$ and then $2.0 \mathrm{ml}$ of the chloroform layer was transferred to a $\mathrm{GC}$ vial to analyze the phenols and indoles by using GC equipped with flame ionization detector (FID) and DB-1 column $(30 \mathrm{~m} \times 0.25 \mathrm{~mm} \times 0.25 \mu \mathrm{m}$, Agilent, Santa Clara, Clara, CA, USA). 0.2 $\mu$ Lwas the sample injection volume with a split ratio of 5:1. The temperature of oven was programmed as follows: initially started from $40{ }^{\circ} \mathrm{C}$ and held for $5 \mathrm{~min}$ and it upgraded to $230{ }^{\circ} \mathrm{C}$ by increasing $10{ }^{\circ} \mathrm{C}$ per minute. Then $230{ }^{\circ} \mathrm{C}$ was kept for $2 \mathrm{~min}$. The injection and detection ports were maintained at $250{ }^{\circ} \mathrm{C}$. The nitrogen was determined by Kjeldahl method [25].

\section{Microbial community analysis}

The bacterial communities of pig slurry samples were analysed by PCR amplification based on $16 \mathrm{~S}$ rRNA gene sequences by using the $27 \mathrm{~F}$ and $518 \mathrm{R}$ primer pair.

\section{PCR amplification for bar-coded pyrosequencing}

In the first step, genomic DNA from slurry sample was isolated by Fast-DNA Spin Kit (MP Bio, Santa Ana, CA, USA) according to the manufacturer's instruction manual. Humic acid, which is inhibiting PCR amplification 
was removed using the Power-Clean DNA Clean-Up Kit (MP Bio, Santa Ana, CA, USA). The amplification conditions of the PCR were followed: initially 1 cycle at $95{ }^{\circ} \mathrm{C}$ for $5 \mathrm{~min}$ and then 30 cycles of $30 \mathrm{~s}$ at $95{ }^{\circ} \mathrm{C}$, $30 \mathrm{~s}$ at $55^{\circ} \mathrm{C}, 72{ }^{\circ} \mathrm{C}$ for $30 \mathrm{~s}$, and finally one cycle was performed at $72{ }^{\circ} \mathrm{C}$ for $7 \mathrm{~min}$.

\section{Pyrosequencing and data analysis}

Pyrosequencing analysis was performed by Chunlab (Seoul, Korea) using the 454 FLX titanium System (Roche, Pleasanton, CA, USA). Sequencing reads of samples were assigned each sequence read to specific sample by their endemic bar codes. PCR primer sequences, barcode, and linker were then removed from the original sequence analysis. For the next analysis, the pyrosequencing reads were selected based on quality filtering process, which are containing more than 300 base pair with an average quality score of more than 25 . EzTaxon-e database were used with the BLAST search tool to perform taxonomic alignment of bacterial high-quality sequence reads. Sequences that could not be matched the EzTaxon-e database, which is at $97 \%$ species level were used to a second-order UCHIME program to identify unrealistic sequences. Operational taxonomic units (OTUs) were generated using a CD-HIT program at with a similarity level of $97 \%$. The Shannon-Weaver diversity index, Chao1 richness index and Goods library coverage were calculated using the Mothur program.

\section{Statistical analysis}

Concentration of odorous compounds data were analysed by using statistical analysis system [26] with using analysis of variance of GLM (General linear model). Significance difference among means of control and treatment groups were compared using Duncan's multiple range tests [27]. Statistical analysis was also performed using Pearson's correlation coefficient to determine the relationship between concentrations of odorous compounds and the relative abundance of bacterial species. Probability value less than 0.05 $(P<0.05)$ was considered for all measured variables.

\section{Results and discussion Growth performance}

Although effects of $\mathrm{CP}$ levels on the concentration of odorous compounds and gut microbiota have been well established [17], little is known about the essential amino acids based diet impact on the microbial community changes in swine gut. Therefore, this study was performed to evaluate the impact of administration of diet formulated based on the ideal protein concept on growth performance, odorous compounds production, and gut microbial communities in pigs.
There was no significant difference in feed intake, BW, ADG, FCR, or amount of total faeces and urine excretion between treatment groups (Table 3). Lopez et al. [28] demonstrated that the ideal protein based diet improved the feed efficiency and carcass leanness in gilts but does not affect the growth performance. Similarly, Hong et al. [29] were also reported that feeding low energy and low protein diets with adequate amino acid supplements had no negative effects on growth performance of growing-finishing pigs. Other studies on piglets and grower-finisher pigs showed that dietary $\mathrm{CP}$ levels can be reduced by formulating pig diets with supplementary amino acids including Lys, Met, Thr, Trp, Phe, His, Val, Ile, and Leu without compromising their growth performance and feed efficiency when feeds were formulated by ideal protein concept [30, 31]. Hence, utilization of these supplements will reduce feed costs and improve profits for swine farmers as well as provide other benefits on environment by reducing $\mathrm{N}$ wastage and concentration of odours.

\section{Effects of dietary treatment on volatile odorous compounds (VOC)}

The effects of pig diets formulated either by 2007 or 2012 feeding standard on levels of VOC are shown in Table 4. Phenolic volatile compounds are one of the major causes for odour in fresh slurry [32, 33]. Phenol was not detected in faecal samples of 2012 treatment group. Biochemical oxygen demand (BOD) levels were significantly decreased $(P<0.05)$ in 2012 group when compared with 2007 group. Levels of p-cresol and phenols were lower $(\mathrm{P}<0.05)$ and $\mathrm{pH}$ tended to be lower $(P=0.07)$ in faeces from pigs fed 2012 diet compare to those fed 2007 diet. Other compounds including phenole, indole, skatole, total Kjeldahl nitrogen (TKN), and $\mathrm{N}$ also tended to decrease in 2012 group, suggesting odorous compound levels were decreased across the board by supplementation of pig diets formulated based on the ideal protein concept.

Table 3 Growth performance of pigs ${ }^{a}$

\begin{tabular}{lllll}
\hline & 2012 & 2007 & fSEM & $p$-value \\
\hline Total feces, ${ }^{b}$ DM, g & 263 & 264 & 20.02 & 0.97 \\
24 h total urine, g & 2708 & 3085 & 137.13 & 0.18 \\
Feed intake, g & 3000 & 3000 & 0 & - \\
Initial ${ }^{\mathrm{c} B W}, 3.30, \mathrm{~kg}$ & 89.38 & 89.38 & 3.05 & 1 \\
Final BW, 4.13, kg & 105 & 106 & 2.42 & 0.85 \\
${ }^{\mathrm{d}}$ ADG, g/day & 1.12 & 1.19 & 0.05 & 0.51 \\
${ }^{\mathrm{e}} \mathrm{FCR}$ & 2.74 & 2.57 & 0.12 & 0.50 \\
\hline
\end{tabular}

${ }^{a}$ Means of 8 pigs per treatment with two replicates

${ }^{\mathrm{b}} D M$ Dry Matter, ${ }^{\mathrm{c}} B W$ Body Weight, ${ }^{\mathrm{d}} A D G$ Average Daily Gain, ${ }^{\mathrm{e}} F C R$ Feed Conversion Ratio ${ }^{f} S E M$ Standard errors of the means 
Table 4 Effects of dietary treatment on VOCs ${ }^{\mathrm{a}}$

\begin{tabular}{llll}
\hline VOC, ppm & 2012 & 2007 & $p$-value \\
\hline phenol & 0 & 0.14 & 0.34 \\
p-Cresol & 15.29 & 23.33 & 0.02 \\
Indole & 1.72 & 1.43 & 0.19 \\
Skatole & 0.08 & 0.22 & 0.44 \\
b phenols & 15.29 & 23.47 & 0.03 \\
Indoles & 1.81 & 1.65 & 0.43 \\
pH & 7.08 & 6.79 & 0.07 \\
${ }^{\mathrm{d} B O D}$ & 6985 & 9255 & 0.06 \\
${ }^{\mathrm{e}} \mathrm{TKN}$ & 920 & 983 & 0.06 \\
$\mathrm{NH} 4-\mathrm{N}$ & 239 & 180 & 0.07 \\
$\mathrm{~N}$ & 0.301 & 0.327 & 0.08 \\
$\mathrm{C}$ & 0.758 & 0.811 & 0.66 \\
$\mathrm{~S}$ & 0.536 & 0.503 & 0.37 \\
$\mathrm{H}$ & 11.645 & 11.602 & 0.88 \\
\hline
\end{tabular}

${ }^{a}$ VOC, volatile odorous compound; means of 8 pigs per treatment with two replicates

${ }^{\mathrm{b}}$ Phenols $=$ Phenol $+\mathrm{p}$-Cresol, ${ }^{\mathrm{C}}$ Indoles $=$ Indole + Skatole, ${ }^{\mathrm{d}} B O D$, Biochemical Oxygen Demand, ${ }^{\mathrm{e}} T K N$ Total Kjeldahl Nitrogen

Canh et al. [34] have demonstrated that low levels of CP with essential amino acid supplements reduces nitrogen excretion and ammonia emission without compromising growth performance of growingfinishing pigs. Reduced $\mathrm{CP}$ content with adequate amino acids supplementation also showed reduced urinary energy loss as well as greater growth performance [35]. In the current study, CP levels included either in 2007 or 2012 diet were not statistically different, but adequate and appropriate ratio of amino acids were provided for 2012 diet (Table 2). There was abundant evidence that pigs fed ideal protein based diets showed maximum utilization of absorbed protein for maintenance and for tissue protein accretion (for growth) with minimum nitrogen (total $\mathrm{N}$ )

Table 5 Effects of dietary treatment on VFA concentration

\begin{tabular}{lllll}
\hline aVFA, ppm & 2012 & 2007 & ${ }^{d}$ SEM & $p$-value \\
\hline Acetic acid & 483 & 443 & 14.34 & 0.17 \\
Propionic acid & 170 & 163 & 5.52 & 0.71 \\
Butyric acid & 83 & 81 & 3.12 & 0.08 \\
Valeric acid & 23 & 21 & 0.71 & 0.56 \\
Iso-butyric acid & 22 & 21 & 1.08 & 0.47 \\
Iso-valeric acid & 39 & 36 & 2.18 & 0.24 \\
bSCFA & 759 & 708 & 22.46 & 0.02 \\
${ }^{c}$ BCFA & 62 & 57 & 3.27 & 0.50
\end{tabular}

${ }^{a} V F A$, volatile fatty acids; means of 8 pigs per treatment with two replicates ${ }^{\mathrm{b}} S C F A$, Short Chain Fatty Acid = Acetic acid + Propionic acid + Butyric acid ${ }^{c} B C F A$, Branched Chain Fatty Acid = Iso-butyric acid + Iso-valeric acid

${ }^{\mathrm{d}}$ SEM Standard errors of the means excretion [36-38]. Reduced N excretion in pig slurry is closely associated with decrease in the odour emission from pig facilities [39]. Total Kjeldahl nitrogen (TKN) is the sum of organic nitrogen, ammonia (NH3), ammonium (NH4) and therefore to calculate total nitrogen, concentration of nitrate- $\mathrm{N}$ and nitrite$\mathrm{N}$ needs to be determined and added to TKN [40]. Total $\mathrm{N}$ and TKN levels, interestingly, tended to be lower but ammonium nitrogen $\left(\mathrm{NH}_{4}-\mathrm{N}\right)$ was higher in 2012 group than in 2007 group in our study. Since conversion of TKN into certain type of $\mathrm{N}$ depends on the type of protein present in the sample, especially what fraction of the protein is composed of nitrogenous amino acids, further study will be necessary to evaluate the intermediate processes of $\mathrm{N}$ conversion.

\section{Effects of dietary treatment on volatile fatty acids (VFA) concentration}

Administration of diets formulated by 2007 or 2012 feeding standard affected the levels of VFA (Table 5). Compare to pigs fed 2007 diet, those fed 2012 diet numerically increased levels of all kinds VFAs analysed in the current study, including acetic acid, propionic acid, butyric acid, valeric acids, iso-butyric acid and isovaleric acid, and branched chain fatty acids (BCFA). Level of SCFA, especially, was significantly increased $(P<0.05)$ in 2012 group $(759 \mathrm{ppm})$ when compared with 2007 group (708 ppm). Dietary proteins and carbohydrates are substrates for microbial fermentation in large intestine [41]. Fermentation of undigested proteins may produce potentially harmful end products including phenols, indoles, ammonia and BCFA [17]. In our current study, however, levels of these odorous compounds tended to be lower by supplementation of 2012 diet, which was formulated with well-balanced amino acid composition. Other studies showed that adequate amino acid supplements or addition of fermentable

Table 6 The pyrosequencing data of bacterial communities in pig feces ${ }^{a}$

\begin{tabular}{lll}
\hline & 2012 & 2007 \\
\hline Total valid reads & 13,264 & 14,018 \\
bOTUs & 635 & 672 \\
Ace & 815 & 824 \\
Chao 1 shared richness & 774 & 777 \\
JackKnife & 829 & 849 \\
Shannon-Weaner index (H) & 3.95 & 4.11 \\
Simpson's index (D) & 0.1 & 0.1 \\
Goods library coverage & 98 & 99
\end{tabular}

${ }^{\mathrm{a} F o u r}$ samples from each treatment were analyzed for pyrosequencing data bOUT Operational Taxonomic Units, Shannon-Weaver (diversity index), Chao1 (richness index) and Goods library coverage were calculated using the Mothur package 


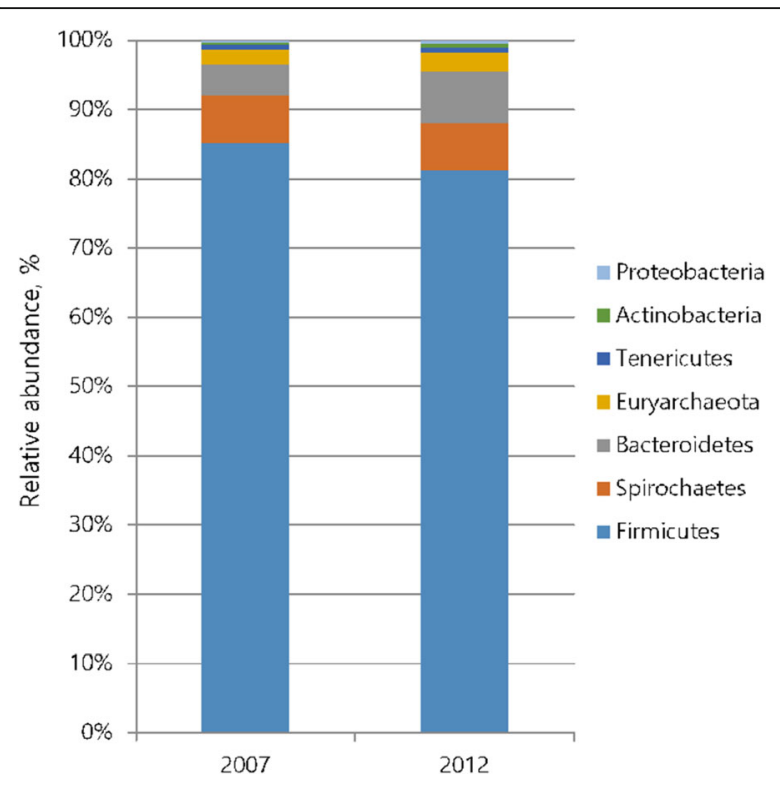

Fig. 1 Bacterial taxonomic compositions of phylum level". "Four samples from each treatment were analyzed for composition of phylum level

carbohydrates in pig diets helped reduce malodorous chemical generation and also improved gut health by conversion of fermentable carbohydrates into SCFA by microbes residing in the large intestine $[42,43]$.

\section{Effects of dietary treatment on microbial communities}

Bacterial communities in animal gut play important roles in degradation of undigested protein and carbohydrates, influence the gut healthiness by inhibiting colonization of pathogens, and maintain gut microbial ecosystem, which is essential to maintain normal gut physiology [44]. Results of $16 \mathrm{~S}$ rDNA sequence analysis performed by using 454 FLX titanium multiplex bar-coded pyrosequencing system to determine the microbial community changes in the faecal samples of pigs fed 2007 or 2012 based diet are shown in Table 6 . The total number of valid readings obtained 13,264 in the 2012 specification and 14,018 in the 2007 specification. Among these, 635 and 672 OTUs were detected in 2012 and 2007 group, respectively. Richness and diversity indices of communities are also showed in Table 6. Significant difference was not appeared in any item, but OUT counts tended to be lower in 2012 group when compared with 2007 group. Bacterial communities of 2007 manure samples showed more Jackknife numbers than those of 2012 group. Values of Shannon-Weaner index $(\mathrm{H})$ were 3.95 and 4.11 in 2012 and 2007, respectively. There was no significant difference in Simpson's index (D) or Goods library coverage between two diet groups.

Bacterial taxonomic compositions in phylum level of feces from pigs fed 2007 or 2012 are shown in Fig. 1. Firmicutes and Bacteroidetes are major microbial phyla in mamals gut $[45,46]$. Concomitant to these reports, results from our current study showed that Firmicutes are most dominant phyla in both groups, followed by Spirochaetes, and Bacteroidetes. At phylum level, the proportion of Firmicutes decreased, while that of Bacteroidetes were significantly increased $(P<0.05)$ in 2012 group. The microbiota in the gut produce SCFA such as acetate, propionate, and butyrate by fermenting nutrients from pig diet. Pigs fed 2012 diet showed a greater level of SCFA, which is known to positively influence the odor concentration [8]. The Bacteroidetes mainly produces propionate and acetate, therefore this phylum has been linked with the higher levels of total SCFAs in 2012 group [47, 48].

Among the total genera detected, the bacterial genera including Bacillus, Coprococcus, and Bacteriodes were increased ( $p<0.05)$, while Oscillibacter, Clostridium, Ruminococcus, and Coprococcus were less in 2012 group than in 2007 group Fig. 2. In species level, Lactobacillus

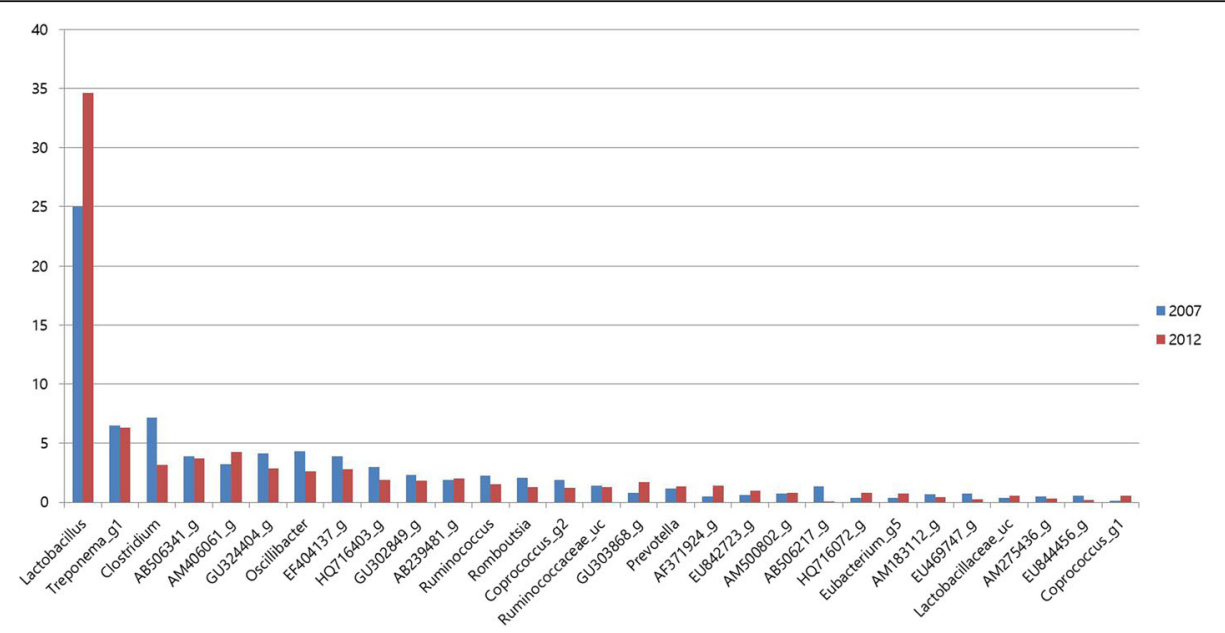

Fig. 2 Bacterial taxonomic compositions of genus level. . ${ }^{*}$ Four samples from each treatment were analyzed for composition of genus level 
species were increased $(P<0.05)$ in 2012 diet fed pigs than control. Lactobacillus species are well known to provide beneficial effects on gut function and health [49]. Moreover, the pathogenic bacteria Clostridium were reduced in 2012 group.

\section{Conclusion}

These data well support our hypothesis that administration of pig diet formulated with ideal protein concept improves gut fermentation and healthiness, as well as helps minimize odorous compound generation from pig farm.

\begin{abstract}
Abbreviations
ADG: Average daily gain; ARC: Agriculture research council; BCFA: Branched chain fatty acids; BOD: Biochemical oxygen demand; CP: Crude protein; EDTA: Ethylenediaminetetraacetic acid; FAO: Food and Agriculture Organization; FCR: Feed conversion ratio; FID: Flame ionization detector; GC: Gas chromatography; GLM: Genernal linear model; INRA: Institute National de la recherche agronomique; NRC: National ResearchCouncil; OECD: Organisation for EconomicCo-operation and Development; OTUs: Operational taxonomic units; PCR: Polymerase chain reaction; SCFA: Short chain fatty acids; TKN: Total Kjeldahl nitrogen; VFA: Total volatile fatty acids; VOS: volatile odorous compounds
\end{abstract}

\section{Acknowledgements}

This study was supported by Rural Development Administration, Republic of Korea with grant no. PJ01181802.

\section{Availability of data and materials}

Authors approved the data and materials availability.

\section{Authors' contributions}

NR and KK mainly performed this study and drafted this manuscript. YJ, OH, and JR were participated in the animal trial and sampling. $\mathrm{HL}$, JJ performed the statistical analysis and discussed the results. YB, JP, and YO were participated in the design and coordination of this manuscript and SP conceived of this study and wrote this manuscript. All authors read and approved this manuscript in final form.

\section{Ethics approval}

All procedures involving animals were approved by the National Institute of Animal Science Animal Care and Use Committee.

\section{Consent for publication}

Not applicable.

\section{Competing interests}

The authors declare that they have no competing interests.

\section{Publisher's Note}

Springer Nature remains neutral with regard to jurisdictional claims in published maps and institutional affiliations.

\footnotetext{
Author details

'Department of Food Science \& Biotechnology, Sejong University, 209 Neundong-ro, Gwangjin-gu, Seoul 05006, South Korea. ${ }^{2}$ National Institute of Animal Science, RDA, Wanju 55365, South Korea.
}

Received: 30 August 2017 Accepted: 31 October 2017

Published online: 11 December 2017

\section{References}

1. Choe JH, Yang HS, Lee SH, Go GW. Characteristics of pork belly consumption in South Korea and their health implication. J Anim Sci Technol. 2015;57:22-9.
2. OECD/FAO. OECD-FAO Agricultural Outlook, vol. 2016-2025. Paris: OECD Publishing; 2016.

3. SH O, See MT. Pork preference for consumers in China, Japan and South Korea. Asian-Aust. J Anim Sci. 2011:25:143-50.

4. National Research Council (NRC). Nutrient requirements of swine. National Academies Press; 2012

5. Colina J, Austin L, Phillip SM. A Review of the Ammonia Issue and Pork Production. Nebraska Swine Reports. 2000. p. 24-5.

6. Mackie RI, Stroot PG, Varel VH. Biochemical identification and biological origin of key odor components in livestock waste. J Anim Sci. 1998;76:1331-42.

7. Spoelstra SF. Origin of objectionable odorous components in piggery wastes and the possibility of applying indicator components for studying odour development. Agr Envir. 1980;5:241-60.

8. Jha R, Berrocoso JF. Dietary fiber and protein fermentation in the intestine of swine and their interactive effects on gut health and on the environment: a review. Anim Feed Sci Technol. 2016;212:18-26.

9. Phung PLD, Becker PM, Aarnink AJA, Jongbloed AW. Van der PeetSchwering CMC. Odour from pig production facilities: its relation to diet (no. 115). In: Agrotech food Innov; 2004.

10. Yasuhara A, Jimbu M. Identification of odorous compounds in fresh and rotten swine manure. Agri Bio Chem. 1984:48:3001-10.

11. Schiffman SS, Bennett JL, Raymer JH. Quantification of odors and odorants from swine operations in North Carolina. Agri Forest Meteo. 2001;108:213-40.

12. Allison MJ. Production of branched-chain volatile fatty acids by certain anaerobic bacteria. Appl Environ Microb. 1978;35:872-7.

13. Freney JR. Sulfur-containing organics. Soil. Biochemist. 1967;1:229-59.

14. Le PD, Aarnink AJA, Jongbloed AW, Van d, Peet-Schwering CMC, Ogink NWM, Verstegen MWA. Effects of dietary crude protein level on odour from pig manure. Animal. 2007;1:734-44.

15. Hobbs PJ, Pain BF, Kay RM, Lee PA. Reduction of odorous compounds in fresh pig slurry by dietary control of crude protein. J Sci food. Agri. 1996;71:508-14.

16. Clark OG, Moehn S, Edeogu I, Price J, Leonard J. Manipulation of dietary protein and nonstarch polysaccharide to control swine manure emissions. J Environ Qual. 2005:34:1461-6.

17. Cho S, Hwang O, Park S. Effect of dietary protein levels on composition of odorous compounds and bacterial ecology in pig manure. Asian-Aust. J Anim Sci. 2015;28:1362-70.

18. Wang TC, Fuller MF. The optimum dietary amino acid pattern for growing pigs. Brit. J Nutr. 1989;62:77-89.

19. Milgen J, Dourmad JY. Concept and application of ideal protein for pigs. J Anim Sci Biotech. 2015;6:15.

20. Boisen $\mathrm{S}$. Ideal protein and its suitability to characterize protein quality in pig feeds. A review. Acta Agri Scand. Section A-Anim Sci. 1997;47:31-8.

21. Munks B, Robinson A, Beach EF, Williams HH. Amino acids in the production of chicken egg and muscle. Poult Sci. 1945;24:459-64.

22. Mitchell HH. Some species and age differences in amino acid requirements. In: Albanese A, editor. Protein and amino acid nutrition. New York: Academic press; 1950. p. 11-43.

23. Institute National de la recherche agronomique (INRA). The diet of non-ruminant animals: pigs, rabbits and poultry. Paris: Institut National de la Recherche Agronomique; 1984. p. 282

24. National Research Council (NRC). Nutrient requirements of swine. 9th ed. Washington: National Academies Press; 1988.

25. AOAC. Official M'ethods of analysis. 16th ed. Assoc. Offic. Anal. Chem., Arlington, VA:1998.

26. SAS. SAS/STAT software, version 9.1. SAS Institute Inc., Cary, N.C. USA.; 2002.

27. Duncan DB. Multiple range and multiple $F$ tests. Biometrics. 1955;1 1:1-42.

28. Lopez J, Goodband RD, Allee GL, Jesse GW, Nelssen JL, Tokach MD, Spiers D, Becker BA. The effects of diets formulated on an ideal protein basis on growth performance, carcass characteristics, and thermal balance of finishing gilts housed in a hot, diurnal environment. J Anim Sci. 1994;72:367-79.

29. Hong JS, Lee GI, Jin XH, Kim YY. Effect of dietary energy levels and phase feeding by protein levels on growth performance, blood profiles and carcass characteristics in growing-finishing pigs. J Anim Sci Technol. 2016;58:37.

30. Toledo JB, Furlan AC, Pozza PC, Carraro J, Moresco G, Ferreira SL, Gallego AG. Reduction of the crude protein content of diets supplemented with essential amino acids for piglets weighing 15 to 30 kilograms. R Bras Zootec. 2014:43:301-9.

31. Tuitoek K, Young LG, De Lange CF, Kerr BJ. The effect of reducing excess dietary amino acids on growing-finishing pig performance: an elevation of the ideal protein concept. J Anim Sci. 1997;75:1575-83. 
32. Sutton AL, Kephart KB, Verstegen MW, Canh TT, Hobbs PJ. Potential for reduction of odorous compounds in swine manure through diet modification. J Anim Sci. 1999;77:430-9.

33. Blanes-Vidal V, Hansen MN, Adamsen APS, Feilberg A, Petersen SO, Jensen BB. Characterization of odor released during handling of swine slurry: part II. Effect of production type, storage and physicochemical characteristics of the slurry. Atmos Environ. 2009;43:3006-14.

34. Canh TT, Aarnink AJA, Schutte JB, Sutton A, Langhout DJ, Verstegen MWA. Dietary protein affects nitrogen excretion and ammonia emission from slurry of growing-finishing pigs. Livest Prod Sci. 1998;56:181-91.

35. Le Bellego L, Van Milgen J, Dubois S, Noblet J. Energy utilization of lowprotein diets in growing pigs. J Anim Sci. 2001;79(5):1259-71.

36. Moughan PJ, Smith WC. Prediction of dietary protein quality based on a model of the digestion and metabolism of nitrogen in the growing pig. New zeal. J Agr Res. 1984;27:501-7.

37. Fuller MF, McWilliam $R$, Wang $T C$, Giles $L R$. The optimum dietary amino acid pattern for growing pigs. Brit. J Nutri. 1989;62:255-67.

38. Heger J, Mengesha S, Vodehnal D. Effect of essential: total nitrogen ratio on protein utilization in the growing pig. Brit. J Nutri. 1998;80:537-44.

39. de Lange K, Nyachoti M, Birkett S. Manipulation of diets to minimize the contribution to environmental pollution. Advances in pork production 1999: 10:173-186.

40. Burke PM, Hill S, Iricanin N, Douglas C, Essex P, Tharin D. Evaluation of preservation methods for nutrient species collected by automatic samplers. Environ Monit Assess. 2002;80:149-73.

41. Meng Q, Kerley MS, Ludden PA, Belyea RL. Fermentation substrate and dilution rate interact to affect microbial growth and efficiency. J Anim Sci. 1999;77:206-14.

42. Aarnink AJA, Verstegen MWA. Nutrition, key factor to reduce environmental load from pig production. Livestock Sci. 2007;109:194-203.

43. Lee KH, Hwang OH, Yang SH, Park KH, Lee JY, Jeun BS, Ohh SJ, Lee SS, Yoo $\mathrm{YH}, \mathrm{Cho} \mathrm{SB}$. The effect of horseradish powder and mushroom waste in fattening pig diet on odorous compound concentration from slurry. J Livest House Env. 2012;18:35-40.

44. Monda V, Villano I, Messina A, Valenzano A, Esposito T, Moscatelli F, Viggiano A, Cibelli G, Chieffi S, Monda M, Messina G. Exercise Modifies the Gut Microbiota with Positive Health Effects. Oxid Med Cell Longev. 2017; ID:3831972.

45. Guo X, Xia X, Tang R, Zhou J, Zhao H, Wang K. Development of a real-time PCR method for Firmicutes and Bacteroidetes in faeces and its application to quantify intestinal population of obese and lean pigs. Lett Appl Microbiol. 2008;47:367-73.

46. Holmes E, Li JV, Athanasiou T, Ashrafian H, Nicholson JK. Understanding the role of gut microbiome-host metabolic signal disruption in health and disease. Trends in microb. 2011;19:349-59.

47. den Besten G, van Eunen K, Groen AK, Venema K, Reijngoud DJ, Bakker BM. The role of short-chain fatty acids in the interplay between diet, gut microbiota, and host energy metabolism. J Lip Res 2013; 54:2325-2340.

48. Ríos-Covián D, Ruas-Madiedo P, Margolles A, Gueimonde M. De los Reyes-Gavilán CG, Salazar N. Intestinal short chain fatty acids and their link with diet and human health. Front Microbiol. 2016;7:185.

49. Le MH, Galle S, Yang Y, Landero JL, Beltranena E, Ganzle MG, Zijlstra RT. Effects of feeding fermented wheat with lactobacillus reuteri on gut morphology, intestinal fermentation, nutrient digestibility, and growth performance in weaned pigs. J Anim Sci. 2016;94:4677-87.

\section{Submit your next manuscript to BioMed Central and we will help you at every step:}

- We accept pre-submission inquiries

- Our selector tool helps you to find the most relevant journal

- We provide round the clock customer support

- Convenient online submission

- Thorough peer review

- Inclusion in PubMed and all major indexing services

- Maximum visibility for your research

Submit your manuscript at www.biomedcentral.com/submit

Biomed Central 